\title{
Sunburn assessment: A critical appraisal of methods and techniques for characterizing the damage to apple fruit
}

\author{
Racskó, J. \\ Department of Horticulture and Crop Science, Ohio Agricultural Research and Development Center, \\ The Ohio State University, 1680 Madison Ave., Wooster,44691-OH, USA, Email: racsko.1@osu.edu
}

\begin{abstract}
Summary: Many methods and techniques have been introduced for measuring alterations in the fruit and in its surrounding environment related to sunburn incidence. The research objectives, fruit materials and the environment to be evaluated dictate the methods to follow. These procedures are either non-destructive and involve techniques that allow us to track the course of sunburn development and related environmental parameters, or destructive and involve the removal of fruit from the tree for field/laboratory measurements. Techniques employed can be used for pre-symptomatic monitoring (before symptoms become visible) or characterizing the symptoms already present. The principles behind the measurements and their usefulness for sunburn assessments are discussed and critically evaluated in this review paper. Descriptions and evaluations of the methods and techniques were made in the following groups: 1. Thermal measurements; 2 . Visual assessments; 3. Fruit quality measurements; 4. Measurements of physiological and biochemical alterations; and 5. Practical evaluation of sunburn damage. Thermal measurements involve methods tracking the ambient temperature and fruit surface temperature, and their relation to sunburn formation. Visual assessments cover all measuring techniques (skin color, chlorophyll fluorescence, radiation reflection, electron microscopy) that are able to detect changes on/in the fruit skin related to sunburn formation. Fruit quality measurements are used to point out differences in qualities (soluble solids, firmness, titratable acidity, and water content) between unaffected and sunburned areas of the fruit. The measurements of physiological and biochemical alterations (gas exchange, pigment analysis, enzyme activity, gene expression) give us a better insight to the mechanism of sunburn formation. Practical evaluations involve many procedures that are used by scientists to characterize the susceptibility of cultivars, evaluate protection technology, etc. For this purpose, the following methods are in use: expressing the percentage of the total fruit surface area affected by sunburn or the percentage of the total number of fruits damaged on the tree, or even a scale based on the severity of the symptoms occurred. All assessing methods and techniques described here have their pros and cons as well as their specific applicability, therefore any of these cannot be favored to use exclusively for assessing sunburn incidence. The combination of these techniques will be the best choice to meet a given research objective perfectly.
\end{abstract}

Key words: apple, sunburn, sunscald, heat stress, temperature, light stress, UV-radiation, chlorophyll fluorescence, electrolyte leakage, heat shock proteins (HSPs), pigments, skin color

\section{Introduction}

Many methods have been introduced for measuring alterations in the fruit and in its surrounding environment related to sunburn incidence. The research objectives, fruit materials and the environment to be evaluated dictate the methods to follow. These procedures are either nondestructive and involve techniques that allow us to track the course of sunburn development and related environmental parameters, or destructive and involve the removal of fruit from the tree for field/laboratory measurements.

Techniques employed can be used for presymptomatic monitoring or describing the symptoms already present. Some current techniques allow presymptomatic observations of changes in the physiological state of fruit, i.e. stress observations before fruits display visible symptoms. In this respect thermal, reflectance and fluorescence imaging have proved their potential by detecting stress-related changes in the pattern of light emission (Chaerle \& van der Straeten, 2000). Using such techniques would allow us to alleviate solar injury stress at an early stage, so avoiding irreversible damage and thus substantially reducing yield loss. While descriptive methods (e.g. pigment analyses, electron microscopy imaging) help to better understand the underlying mechanisms of sunburn formation. All assessing techniques described here have their pros and cons as well as their specific applicability; therefore any of those cannot be favored to use exclusively to assess sunburn incidence. The combination of the following techniques will be the best choice to meet a given research objective perfectly. The principles behind the measurements and their usefulness for sunburn assessments will be discussed here.

\section{Thermal measurements}

First measurements related to sunburn on apples were done by Overholser et al. (1923) who made comparisons between temperatures of apple fruits located in the shaded and exposed sides of the canopy. Harvey (1923, 1925) compared ambient air temperature and surface temperatures of the sunny and shaded sides of various fruits including apples. Records were taken with inserted thermocouples. 
Similarly, Brooks \& Fisher (1926) compared air temperature to fruit surface temperature (FST) of 10 apple cultivars. Although their method of pushing the sensory bulb of a thermometer beneath the skin was imprecise, results were still very informative and allowed comparisons among cultivars. Comparative fruit surface temperatures were measured by Meyer (1932) as well, however, his results cannot be considered to be decisive as he used detached apples exposed to natural sunlight in his experiment. Since then, similar methods were employed by several researchers to monitor FSTs of apples susceptible to sunburn (Unrath, 1972; Thorpe, 1974; Bergh et al., 1980; Kotzé et al., 1988; Parchomchuk \& Meheriuk, 1996; Glenn et al., 2002; Adams \& Valdés, 2002; Evans, 2004; Gindaba \& Wand, 2005; Saudreau et al., 2007; Schrader, 2009).

Such measurements characterize temperature changes very well and with fruit-inserted thermocouples connected to data logger with automated data recording make this procedure easy. However, they have some disadvantages including that the insertion of thermocouples wounds the fruit (Prohens et al., 2004) and makes the measurements on the same fruit unrepeatable in later times (thermocouples are usually used in a fruit for up to 24-h for FST measurements) (Ferguson et al., 1998). Small variations in the depth of insertion of the thermocouple can also significantly affect the results and cause abnormal pigmentation or fruit development. To solve these problems, Felicetti (2003), Schrader et al. (2003), Felicetti \& Schrader (2008b) and Seo et al. (2008) used thermocouples placed on the fruit surface, instead of insertion, and held in place by a small fabric adhesive bandage. This tape method was preferred for long term measurements, as the thermocouples could be moved as fruit changed position and peel was not damaged to allow entry of pathogens. The main aim of these measurements with thermocouples was to monitor FST throughout the season and examine daily whether sunburn had occurred. If so, the date of event was recorded and FST for several days preceding incidence of sunburn was reviewed to determine the highest temperature that had occurred prior to the sunburn event. This was recorded as the threshold temperature of naturally occurring sunburn of a given cultivar (Schrader et al., 2001). The disadvantage of this method is that sudden weather changes can cause FST to increase markedly above what it had been previously. Sunburn occurs, but may cause us to overestimate the threshold temperature for sunburn. This explains why the threshold temperatures established with this FST-tracking method are generally higher than for experimental induction methods.

Such FST-tracking point measurements can be used for screening purposes only, they cannot reveal spatial heterogeneity in FST (the angle of the sun is gradually changing during the day causing the highest temperature point is gradually shifted on the fruit surface). Therefore, it seemed to the use of other temperature measuring procedures need to be employed for a more accurate observation of FST. Infrared thermometry (e.g. Raytek Corp. - Raynger series; Heimann Corp. - KT models) and thermography (e.g. FLIR
Systems - ThermaCAM series, AGEMA Systems Theromovision series) allowed non-destructive and remote determination of FSTs by detecting long wave infrared radiation $(8-14 \mu \mathrm{m})$ emitted from the fruit (Chaerle \& van der Straeten, 2000). Thermometry seemed to be a very useful tool in apple FST measurements (Thorpe, 1974). In case of thermography, computer software transforms radiation data into thermal images in which temperature levels are indicated by a false-color gradient. Modifications in the FST caused by adverse solar radiation lead to changes in physiological and biochemical procedures of the fruit as a result of active natural protective mechanisms (e.g. induction of HSPs genes). The associated changes in patterns of heat balance of the fruit surface can be monitored instantly and remotely by thermographic imaging. These technologies, therefore, seemed to be more useful when studying the course of sunburn development or detect temperature differences on the fruit surface in apples (Glenn et al., 2002; Evans, 2004; Gindaba \& Wand, 2005, 2008; van den Dool, 2006; Wand et al., 2006), tomatoes (Adams \& Valdés, 2002) and pepino fruits (Prohens et al., 2004).

\section{Visual assessments}

As colors of sunburn symptoms are readily visible and distinguishable from the non-affected fruit surface, it seems practical to determine the degree of change in color. Color changes in apples associated with sunburn damage have been determined using various objective charts (e.g. Deciduous Fruit Board chart series in South Africa) (Wand et al., 2006; Gindaba \& Wand, 2008) and with the use of colorimeter (e.g. Minolta - CR-series, Gardner types) (Lurie et al., 1991). Felicetti \& Schrader (2008a, 2009a, b) used the most common technique to compare peel colors of undamaged and various stages of sunburned fruit. They determined the CIE $L^{*} a^{*} b^{*}\left(L^{*}\right.$, lightness coordinate; $a^{*}$, red/green coordinate; $b^{*}$, yellow/blue coordinate) color space and calculated hue angle and chroma values.

The use of chlorophyll fluorescence in vivo to visually detect photoinhibitory damage has been described by Critchley \& Smillie (1981). Hence, by measuring the yield of chlorophyll fluorescence, information about changes in the efficiency of photochemistry and heat dissipation can be gained (Maxwell \& Johnson, 2000). Although fluorescence measurements may sometimes provide a useful measure of the photosynthetic performance of plants, its real strength lies in its ability to give information that is not readily available in other ways. In particular, fluorescence can give insights into the ability of a plant to tolerate environmental stresses and into the extent to which those stresses have damaged the photosynthetic apparatus (Maxwell \& Johnson, 2000; Song et al., 2001; Willits \& Peet, 2001). Smillie \& Hetherington (1983) proved that it can be used to assess effects of irradiating apples with UV light under laboratory conditions and to follow photobleaching resulting from sunburn of apples in the orchard. While these measurements on sunburned apples do not identify the primary cause of the 
injury they do provide a means of measuring its effect. Identification of the actual injurious wave length bands or combination of these contributing to sunburn should be amenable to study by chlorophyll fluorescence techniques and it should also be possible to detect early stress injuries, e.g. photoinhibition, which precede the loss of chlorophyll. As in the case of UV radiation of apples, the decline in log $\mathrm{F}_{\mathrm{R}}$ was linearly related to the time of irradiation and it seems feasible to use fluorescence in vivo to screen for resistance and adaptation to UV light, and also to intense visible light (Smillie \& Hetherington, 1983). Seo et al. (2008) used a portable modulated flourometer (OS5-FM type, OptiSciences) to detect heat stress-induced changes in chlorophyll fluorescence and relate heat stress indicators to the physical symptoms of sunburn on 'Fuji' apple fruit. $M a \&$ Cheng (2003) and later Chen \& Cheng (2007) used a custommade pulse-modulated flourometer (FMS2 type, Hansatech) to compare chlorophyll fluorescence of sunny and shaded sides of 'Gala' and 'Smoothee' apple fruits.

The determination of the radiation reflection spectra is also a useful tool in the visual assessments related to sunburn damage on apples. Knowing the specific conditions (radiance) of the formation of each type of sunburn symptoms, it can help to estimate the absolute efficiency of sprayable sunburn protectants such as Surround. For this purpose, spectrometer (PP Sytems, Unysis type) was used and the reflected radiation (195-400 nm) was measured by Glenn et al. (2002). They expressed the radiation reflection as a percentage of the control reflection spectrum. Whole fruit reflectance spectra in 400-800 nm range were recorded by Merzlyak et al. (1998, 2002) with a Hitachi spectrophotometer. In latter case, they compared the reflection spectra of the sunny and shaded sides of apple fruits for four cultivars ('Antonovka obyknovennaya', 'Zhigulevskoye', 'Renet Simirenko' and 'Granny Smith'). Between the reflectance of apple fruit peel of sunny and shaded sides, Ma \& Cheng (2003) and later Chen \& Cheng (2007) made comparisons using a spectroradiometer (Li-type, LI-COR Systems). Ding \& Fuchigami (2004) also confirmed the applicability of the reflectance spectroscopy (FOSS NIR system) in early detection of sunburn in 'Fuji' apples.

For visual characterization of sunburn damage on apple fruit, scanning electron microscopy imaging technique was used by Andrews \& Johnson (1996, 1997). They were able to characterize alterations in the wax cuticle and in structural organizations in the sunburned peel and detected intercellular damage prior to the appearance of the visual symptoms of sunburn. Later, Hao \& Huang (2004) used scanning electron microscopy for similar purposes. Felicetti (2003) and Felicetti \& Schrader (2008b) employed the same technique for characterizing photooxidative sunburn symptoms in transverse sections of the apple skin.

\section{Fruit quality measurements}

Probably, Tustin et al. (1993) were the first who assessed quality of 'Braeburn' apple fruits with various extent of blush area $(<40 \%, 40-70 \%$ and $>70 \%)$ on the surface including a group of fruits with "marginal sunburn discoloration". Quality and maturity indices used were starch pattern index, firmness and soluble solids concentration. Later, Curry (1994) used 'Granny Smith' and 'Red Delicious' cultivars and sorted fruits into six categories based on the extent of sunburn damage; none, "light", "bleached", "bronzed", "buckskin", and "cracked". Each fruit was subdivided into exposed and shaded halves and each half was evaluated for firmness, soluble solids and acidity. Tissue samples were analyzed for sugars, total nitrogen, and mineral content. Later, Racskó et al. (2005b) pointed out the alterations in fruit quality parameters within the sunburned surface of 'Idared' apple fruit. Besides skin color and the depth of tissue damage, they evaluated the changes in firmess and soluble solids with various distances from the center of the sunburned spot. Although, this study provided many details on sunburn effect on fruit qualities, authors did not indicate which type of sunburn was studied. Based on the description, it seems likely that Racskó et al. (2005b) studied sunburn necrosis as they did indicate that plant cells, suffering from sunburn, died.

Recently, Schrader et al. (2008) and Schrader \& Kahn (2009) have determined internal fruit quality traits of apples at various stages of sunburn browning. They extended the firmness and soluble solids measurements on flesh tissues beneath the sunburned area with the determination of titratable acidity and water content. They studied 'Fuji' at monthly intervals from harvest to 6 months for regular atmosphere (RA) cold storage and five cultivars at harvest and after 3 and 6 months of RA cold storage. As severity of sunburn browning increased from $\mathrm{S}-1$ to $\mathrm{S}-4$, firmness and soluble solids increased whereas titratable acidity declined as time as time in cold storage increased. This study provided useful practical information on postharvest life of apple fruits with sunburn browning. More recently, Schrader et al. (2009) compared these fruit quality traits on the sun-exposed side, the shaded side and the shoulder between the two to ascertain the changes in fruit quality in the various sides of fruit with different degrees of sunburn. These findings are extremely important because apples with moderate sunburn browning are generally marketed.

\section{Measurements of physiological and biochemical alterations}

In the early 1900s, Brooks \& Fisher (1926) made comparisons in sap concentrations, i.e. osmotic pressures of the sunny and shaded sides of 'Winter Banana' apples. They used this procedure to point out the role of sap concentration in heat resistance found in adjacent tissues subjected to different degrees of exposure.

Electrolyte leakage of fruit cells which is correlated with the integrity of cell membranes, provides an objective measurement of the effect of excessive irradiation. When fruit tissue is injured by high temperature, membrane permeability is increased, and electrolytes diffuse out of the cells. This allows the assessment of relative heat damage by 
measuring the amount of electrolyte leakage (Chen et al., 1982). Even if this method is destructive, it is very useful to estimate the relative thermostability of fruit cell membranes. Several authors employed this technique using electrolyte conductivity meters (Inaba \& Crandall, 1988; Schrader et al., 2001; Felicetti, 2003; Prohens et al., 2004; Felicetti \& Schrader, 2008b). Even with a sigmoidal response curve fitted to the electrolyte leakage data across various treatment temperatures makes it possible to predict critical high temperatures at which sunburn symptoms occur (Inaba \& Crandall, 1988).

First, Le Grange et al. (2002) and later Gindaba \& Wand (2007a, b) measured gas exchange attributes (photosynthetic light-response and $\mathrm{CO}_{2}$-response, stomatal conductance) of apple leaves when comparing various sunburn control measures (evaporative cooling, kaolin particle film application and shade net). They used these techniques aiming to identify a technology that effectively reduces sunburn with minimum negative effects on tree physiological processes. This investigation extended earlier studies on comparison of midday gas exchange by the application of shade net and kaolin particle film technology (Glenn et al., 2003; Jifon \& Syvertsen, 2003). Later, Chen \& Cheng (2007) and Chen et al. (2009) were able to measure dark respiration and photosynthetic $\mathrm{O}_{2}$ evolution rates of heat treated apple peel discs with a ChloroLab-2 liquid-phase oxygen electrode system (Hansatech Instruments). This technique of measuring fruit peel gas exchange responses to environmental conditions related to sunburn damage provides new insights into fruit physiology. Glenn et al. (2008) used CIRAS-2 gas analyzer (PP Systems) to measure fruit surface respiration of UV-irradiated and heat treated apple peel disks. They extracted small pieces of peel and flesh cores from apple fruits and placed them on glass slide, where the base and exposed edges of fruit samples were coated with silicone grease to prevent gas exchange from surfaces other than the peel. With this technique they were able to predict possible adaptation strategies (e.g. UV repair mechanisms) by examining both the maximum quantum efficiency of photosystem II and dark respiration.

Excessive radiation causes significant changes in the pigment composition of apple fruits. Most often chlorophyll degradation occurs accompanied with the increase of other pigments actively involved in photoprotective mechanisms of the fruit (e.g. flavonoids can serve as radical scavengers). Therefore, it is a frequent practice to evaluate sunburn damage with measuring the amounts and relative ratios of various pigments. Chlorophyll $a$ and $b$, and total carotenoids and phenolics are usually determined spectrophotometrically in methanol or mixed extracts (Merzlyak et al., 1998, 2002; Yuri et al., 2000b; Reay \& Lancaster, 2001; Solovchenko et al., 2001; Hao et al., 2004; van den Dool, 2006; Chen \& Cheng, 2007; Chen et al., 2009; Iamsub et al., 2009) rather than separate them by HPLC which is both costly in time and materials and often difficult to correct for measurements at a single wavelength and for losses during the extract manipulations (Wellburn, 1994). However, HPLC technique is essential for quantification of individual pigments (Awad et al., 2000, 2001; Ma \& Cheng, 2003; Solovchenko \& Schmitz-Eiberger, 2003; Ding \& Fuchigami, 2004; Hao et al., 2004; Takos et al., 2006; Wand et al., 2006). Felicetti \& Schrader (2008a, 2009a, b) used HPLC technique for the determination of â-carotene, lutein, idaen, violaxanthin, zeaxanthin, antheraxanthin, quercetin and individual quercetin glycosides (quercetin 3-arabinofuranoside, quercetin 3-arabinopyranoside, quercetin 3-galactoside, quercetin 3-glucoside + quercetin 3-rutinoside, quercetin 3xyloside, quercetin 3-rhamnoside), chlorogenic acid and epicatechin associated with sunburn browning.

In a comparison of sunny and shaded sides of apple fruits, Ma \& Cheng (2003) and Chen \& Cheng (2007) determined the activity of various enzymes (superoxide dismutase, ascorbate peroxidase, catalase, monodehydroascorbate reductase, dehydroascorbate reducatse, gluthation reductase, NADP-glyceraldehyde-3-phosphate dhydrogenase, phosphoribulokinase, stomatal fructose-1,6-biphosphatase, sucrose phosphate synthase) involved in natural protective mechanisms against excessive solar radiation. With these methods, they were able to point out differences in the photosynthetic capacity and thermotolerance in the sunny and shaded sides of apple fruits. Zhang et al. (2007) measured 5'-nucleotidase activity to study sunburn-related membrane functions under high temperature and relative humidity stress. By determining PPO activity, Zhang et al. (2008) pointed out a causal relationship between the browning process of sunburned fruit and PPO activity. Several other chemical compounds were also analyzed from sunburned fruit peels and compared to unaffected samples in order to track the changes caused by excessive solar radiation; ascorbic acid (Lurie et al., 1991; Iamsub et al., 2009), amino acids (Lurie et al., 1991), malonaldehyde (Lurie et al., 1991), malondialdehyde (Iamsub et al., 2009) and reducing sugars (Lurie et al., 1991). Besides the mass of data reported on various compounds in several papers, authors were not always able to exactly explain the physiological role of the measured compounds related to sunburn damage.

Lately, several newer techniques are also available to study plant response to excessive environmental conditions at a cellular level. Such tool is to track the gene expression of heat shock proteins (HSPs) as HSPs synthesis is a typical response of fruits when subjected to high temperatures (Lurie \& Klein, 1990; Ferguson et al., 1994; Woolf et al., 1995). However, most studies of high temperature response have been done on laboratory materials such as cultured cells, micro-organisms or laboratory-grown plants. The experimental material was often subjected to a rapid, large increase in temperature and this has led to a perception that high temperature responses are induced by abnormal conditions. However, plants in the field can encounter HSPsinducing temperatures during normal diurnal temperature cycles in the warmer seasons. This was confirmed by Ferguson et al. (1998) who used Northern analysis in field conditions. They studied the expression of HSP70 and 
smHSP genes associated with high daily flesh temperatures of 'Braeburn' apples. The major advantage of such analysis is to help determine how fruit acclimate to survive conditions of high temperature and solar irradiation. Later, Ritenour et al. $(1998,2001)$ used Western immunoblot analyses to measure the differences in large HSP and smHSP between apple fruits grown in the shade or under the direct sun. To point out the genetic impact on heat shock response of apple fruit, they used cultivars characterized with various susceptibilities to sunburn ('Fuji', 'Jonagold', 'Criterion', 'Gala' and 'Red Delicious').

\section{Practical evaluation of sunburn damage}

The degree of sunburn can be evaluated by different procedures. Many of the scientists used measures based on the percentage of the total fruit surface area affected by sunburn (Gaus \& Rogoyski, 1992; Melgarejo et al., 2004; Wünsche et al., 2004a; Racskó et al., 2005a). The accuracy of such estimates of the visible surface area depends on the clarity of sunburn symptoms on the fruit surface which is sometimes difficult as sunburn may have different levels of visibility depending on the color of the skin, the cultivar susceptibility, the environmental conditions, etc. In some cases fruit may even appear to be unaffected, when in fact sunburn damage exists but in the subepidermal tissues. This is the typical case of "sunburn scald" in "Granny Smith' apples where symptoms appear postharvest during cold storage (Hall \& Scott, 1989; Contreras, 1999). In normal cases, the symptoms are generally easily recognizable for photooxidative sunburn, however, there is often an intermediately or differently colored ring, called "halo" area (Felicetti \& Schrader, 2009a, b), between the unaffected fruit surface and the sunburn spot of sunburn browning and sunburn necrosis that makes the evaluation difficult.

Others expressed the percentage of the total number of fruits on the tree damaged (Bergh et al., 1980; Miller, 1982; Kotzé et al., 1988; Rogoyski et al., 1993; Contreras, 1999; Schupp et al., 2002a, b, 2004; Stampar et al., 2002; Palmer et al., 2003; Kreuzwieser \& Kelderer, 2004; Raffo \& Iglesias, 2004; Blanco, 2005; Gindaba \& Wand, 2005, 2008; Benegas et al., 2006; Dos Santos \& Wamser, 2006; Benegas \& Rodríguez, 2007; Do Amarante et al., 2007; Araya, 2008; Iamsub et al., 2008, 2009; Racskó et al., 2008, 2009; Tapia, 2008). These evaluation methods seemed to be very useful from practical point of view (e.g. comparing cultivar susceptibility), however, they did not inform about which type of sunburn (sunburn necrosis, sunburn browning or photooxidative sunburn) was observed, i.e. what environmental factor(s) caused the symptoms observed. Without knowing of the existence of various sunburn types, Warrington et al. (1996) already recorded the incidence of two types; photooxidative sunburn and sunburn browning as whitening and red/orange blush respectively.

Others characterized sunburn damage based on the severity of the symptoms, i.e. the degree of discoloration on the exposed fruit surface (Allmendinger et al., 1943; Lurie et al., 1991; Curry, 1994; Parchomchuk \& Meheriuk, 1996; Fallahi et al., 1998; Contreras, 1999; Yuri et al., 2000a; Yuri, 2001; Glenn et al., 2002; Middleton et al., 2002; Wünsche et al., 2001, 2004b; Hao \& Huang, 2004; Prohens et al., 2004; Raffo \& Iglesias, 2004; Blanco, 2005; Gindaba \& Wand, 2005; Wand et al., 2006; O'Connell \& Goodwin, 2007). This method gives a picture of the severity of sunburn and is quite useful, for instance, to evaluate the effectiveness of various protecting methods/chemicals. However, the problem with such estimating technique is that it is too subjective; the scoring value greatly depends on the evaluator's own judgement, and therefore the results of different researchers are not comparable. From the descriptions of the methods used, it seems likely that above authors used a scale of various numbers ( 2 to 5 , or even to 10) of stages of sunburn development from mild bleaching or mild sunburn browning to severe sunburn necrosis. This classification is based on skin color changes mostly, representing a defective view, that is, sunburn necrosis exclusively forms from sunburn browning or from photooxidative sunburn through sunburn browning on a direct way. However, sunburn browning is not a necessary precondition of the formation of sunburn necrosis. Sunburn necrosis or necrotic symptoms can, however, develop in other ways as well, i.e. from sunburn browning or photooxidative sunburn depending on the environmental conditions. On the other hand, photooxidative sunburn ? sunburn browning ? sunburn necrosis is not the pathway of sunburn development, i.e. the increasing extent of damage, even if the color of the symptoms (white ? yellow/mild brown ? dark brown, respectively) would assume it. Again, we stress here that color changes on the exposed fruit surface are not closely correlated with the degree of sunburn damage, therefore cannot be used as an accurate descriptor.

\section{References}

Adams, S.R. \& Valdés, V.M. (2002): The effect of periods of high temperature and manipulating fruit load on the pattern of tomato yields. J. Hort. Sci. Biotechn. 77: 461-466.

Allmendinger, D.F., Overley, F.L. \& O’Neill, W.J. (1943): Experts study on apple sunburn - Is fluorine spray more to blame than lead arsenate? Better Fruit 38, (1): 6-7.

Andrews, P.K. \& Johnson, J.R. (1996): Physiology of sunburn development in apples. Good Fruit Grower 47, (12): 33-36.

Andrews, P.K. \& Johnson, J.R. (1997): Anatomical changes and antioxidant levels in the peel of sunscald damaged apple fruit. Plant Physiol. 114, (3-Suppl.): 103. (Abstract)

Araya, L.M.V. (2008): Efecto de distintos niveles de carga frutal sobre el caliber, calidad de la fruta y desarrollo vegetative del árbol, en manzanos cv. Ultra Red Gala, sobre portainjerto MM.111 [Effect of different crop load levels on diameter, fruit quality and vegetative development of Ultra Red Gala apple on MM.111 rootstock]. MS Thesis, University of Talca, Chile. (In Spanish with English summary)

Awad, M.A., de Jager, A. \& van Westing, L.M. (2000): Flavonoid and chlorogenic acid levels in apple fruit: characterization of variation. Sci. Hort. 83: 249-263. 
Awad, M.A., Wagenmakers, P.S. \& de Jager, A. (2001): Effects of light on flavonoid and chlorogenic acid levels in the skin of 'Jonagold' apples. Sci. Hort. 88: 289-298.

Benegas, R.M.D. \& Rodríguez, A. (2007): Asoleado [Sunburn]. Proy. Reg. No. 618024 "Implementación de una red de parcelas demonstrativas". INTA EEA Alto Valle, Río Negro, Patagonia, Argentina. 12. pp. (In Spanish) Online at

http://www.inta.gov.ar/altovalle/actividad/investigacion/fisiologia/ pdf/folleto_asoleado.pdf

Benegas, R.M.D., Rodríguez, R. \& Rodríguez, A. (2006): Distribución lumínica en diferentes combinaciones portainjerto /variedad en manzana cv. Mondial Gala y su efecto sobre la calidad de la fruta y parámetros vegetativos [Light distribution in different rootstock-variety combinations of Mondial Gala apple trees and its effect on fruit quality and vegetative parameters]. RIA 35, (2): 53-69. (In Spanish with English summary)

Bergh, O., Franken, J., van Zyl., E.J., Kloppers, F. \& Dempers, A. (1980): Sunburn on apples - preliminary results of an investigation conducted during the 1978/79 season. Deciduous Fruit Grower 30, (1): 8-22.

Blanco, G.E.U. (2005): Efecto de aplicaciones foliares de ceras y ácidos grasos sobre la partidura en manzanas y otras alteraciones de postcosecha cvs. Gala y Fuji, en tres localidades temporada 20042005 [Effect of foliar applications of waxes and fatty acids on cracking of Gala and Fuji apples and other postharvest alterations at three locations in the 2004-2005 season]. MS Thesis, University of Talca, Chile. 55. p. (In Spanish with English summary)

Brooks, C. \& Fisher, D.F. (1926): Some high-temperature effects in apples: Contrast in the two sides of an apple. J. Agric. Res. 32, (1): 1-16.

Chaerle, L. \& van der Straeten, D. (2000): Imaging techniques and the early detection of plant stress. Trends in Plant Sci. 5: 495-501.

Chen, H-H., Shen, Z-Y. \& Li, P.H. (1982): Adaptibility of crop plants to high temperature stress. Crop Sci. 22: 719-725.

Chen, L-S. \& Cheng, L. (2007): The sun-exposed peel of apple fruit has a higher photosynthetic capacity than the shaded peel. Funct. Plant. Biol. 34: 1038-1048.

Chen, L-S., Li, P. \& Cheng, L. (2009): Comparison of thermotolerance of sun-exposed peel and shaded peel of 'Fuji' apple. Environ. Exp. Bot. 66: 110-116.

Critchley, C. \& Smillie, R.M. (1981): Leaf chlorophyll fluorescence as an indicator of high light stress (photoinhibition) in Cucumis sativus L. Aust. J. Plant Physiol. 8: 133-141.

Contreras, J.L.I. (1999): Desarrollo de "sunscald" en manzana cv. Granny Smith en almacenaje refrigerado [Development of "sunscald" in Granny Smith apple in cold storage]. MS Thesis, University of Talca, Chile. (In Spanish with English summary)

Curry, E. (1994): Effect of excessive solar radiation on fruit quality and mineral nutrition of 'Granny Smith' 'Delicious' apples. HortScience 29, (5): 438. (Abstract)

Ding, P. \& Fuchigami, L.H. (2004): Application of reflectance spectroscopy in 'Fuji' apple sunburn early detection. HortScience 39, (4): 772. (Abstract)

Do Amarante, C.V.T., Steffens, C.A., Mota, C.S. \& dos Santos, H.P. (2007): Radiação, fotossíntese, rendimento e qualidade de frutos em macieiras 'Royal Gala' cobertas com telas antigranizo [Radiation, photosynthesis, yield and fruit quality of 'Royal Gala' apples under hail protection nets]. Pesquisa Agropecuaria Brasileira 42, (7): 925-931. (In Portuguese with English summary)

Dos Santos, J.P. \& Wamser, A.F. (2006): Efeito do ensacamento de frutos sobre danos causados por fatores bióticos e abióticos em pomar orgânico de macieira [Fruit bagging effect on the damage caused by biotic and abiotic factors in an organic apple orchard]. Revista Brasileira de Fruticultura 28, (2): 168-171. (In Portuguese with English summary)

Evans, R.G. (2004): Energy balance of apples under evaporative cooling. Trans. ASAE 47, (4): 1029-1037.

Fallahi, E., Hafez, S.L., Colt, W.M. \& Seyedbagheri, M.M. (1998): Effects of metam sodium and rootstock on plant-parasitic nematodes, tree growth, yield, fruit quality, and leaf minerals in 'Braeburn' apple. Nematropica 28, (1): 71-79.

Felicetti, D.A. (2003): Characterization of a third type of apple sunburn caused by sudden exposure of shaded apples to sunlight. MS Thesis, Washington State Univ., Pullman, WA. 22. pp.

Felicetti, D.A. \& Schrader, L.E. (2009a): Changes in pigment concentrations associated with sunburn browning of five apple cultivars. I. Chlorophylls and carotenoids. Plant Sci. 176: 78-83.

Felicetti, D.A. \& Schrader, L.E. (2009b): Changes in pigment concentrations associated with sunburn browning of five apple cultivars. II. Phenolics. Plant Sci. 176: 84-89.

Felicetti, D.A. \& Schrader, L.E. (2008a): Changes in pigment concentrations associated with the degree of sunburn browning of 'Fuji' apple. J. Amer. Soc. Hort. Sci. 133: 27-34.

Felicetti, D.A. \& Schrader, L.E. (2008b): Photooxidative sunburn of apples: Characterization of a third type of apple sunburn. Int. J. Hort. Sci. 8, (3): 160-172.

Ferguson, I.B., Lurie, S. \& Bowen, J.H. (1994): Protein synthesis and breakdown during heat shock of cultured pear (Pyrus communis L.). Plant Physiol. 104: 1429-1437.

Ferguson, I.B., Snelgar, W., Lay Yee, M., Watkins, C.B. \& Bowen, J.H. (1998): Expression of heat shock protein genes in apple fruit in the field. Austral. J. Plant Physiol. 25: 155-163.

Gaus, A. \& Rogoyski, M. (1992): Cellulose fibers show promise in reducing sunburn injury of 'Paulared' apples. HortScience 27, (6): 150. (Abstract)

Gindaba, J. \& Wand, S.J.E. (2005): Comparative effects of evaporative cooling, kaolin particle film, and shade net on sunburn and fruit quality in apples. Hort. Science 40, (3): 592-596.

Gindaba, J. \& Wand, S.J.E. (2007a): Climate-ameliorating measures influence photosynthetic gas exchange of apple leaves: Research article. Ann. Appl. Biol. 150, (1): 75-80.

Gindaba, J. \& Wand, S.J.E. (2007b): Do fruit sunburn control measures affect leaf photosynthetic rate and stomatal conductance in 'Royal Gala' apple? Environ. Exp. Bot. 59: 160-165.

Gindaba, J. \& Wand, S.J.E. (2008): Comparison of climate ameliorating measures to control sunburn on 'Fuji' apples. Acta Hort. 772: 59-64.

Glenn, D.M., Prado, E., Erez, A., McFerson, J. \& Puterka, G.J. (2002): A reflective, processed kaolin particle film affects fruit temperature, radiation reflection, and solar injury in apple. J. Amer. Soc. Hort. Sci. 127: 188-193.

Glenn, D.M., Prado, E., Erez, A., Puterka, G.J. \& Gundrum, P. (2003): Particle films affect carbon assimilation and yield in 'Empire' apple. J. Amer. Soc. Hort. Sci. 128: 356-362.

Glenn, D.M., Wünsche, J.N., McIvor, I., Nissen, R. \& George, A. (2008): Ultraviolet radiation effects on fruit surface respiration and chlorophyll fluorescence. J. Hort. Sci. Biotechnol. 83, (1): 43-50.

Hall, E.G. \& Scott, K.J. (1989): Pome Fruit, (In: Beattie, B.B., 
McGlasson, W.B.\& Wade, N.L. (eds.) Postharvest Diseases of Horticultural Produce. Vol. 1. Temperate Fruit.) CSIRO, Australia.

Hao, Y-Y. \& Huang, W-D. (2004): Changes in antioxidative system and cell ultrastructure in the fruit peels of apple during sunburn development. J. Plant Physiol. Mol. Biol. 30, (1): 19-26.

Hao, Y-Y., Huang, W-D. \& Zhang, W-H. (2004): Studies on changes in phenolics in the apple fruit peel in response to light intensity. Agric. Sci. China 3, (2): 108-115. (In Chienese)

Harvey, R.B. (1923): Conditions for heat canker and sunscald in plants. Minn. Hort. 51: 331-334.

Harvey, R.B. (1925): Conditions for heat canker and sunscald in plants. J. Forestry 23: 292-294.

Iamsub, K., Sekozawa, J., Sugaya, S., Gemma, H. \& Kamuro, J. (2009): Alleviating sunburn injury in apple fruit using natural and fertilizer forms of S-abscisic acid and its underlying mechanism. J. Food Agric. Environm. 7, (2): 446-452.

Iamsub, K., Sekozawa, J., Sugaya, S., Gemma, H. \& Kamuro, J. (2008): Improvement of fruit quality by S-ABA and the fertilizer formulated $\mathrm{K}, \mathrm{P}, \mathrm{Mg}$, Bo, Mn containing S-ABA as pre-harvest application on peaches and apples. Acta Hort. 804: 219-224.

Inaba, M. \& Crandall, P.G. (1988): Electrolyte leakage as an indicator of high-temperature injury to harvested mature green tomatoes. J. Amer. Soc. Hort. Sci. 113: 96-99.

Jifon, J.L. \& Syvertsen, J.P. (2003): Moderate shade can increase net gas exchange and reduce photoinhibition in citrus leaves. Tree Physiol. 23: 119-127.

Kotzé, W.A.G., Carreira, J.A., Beukes, O. \& Redelinghuys, A.U. (1988): Effect of evaporative cooling on the growth, yield and fruit quality of apples. Deciduous Fruit Grower 38: 20-24.

Kreuzweiser, A. \& Kelderer, M. (2004): Biologischer und integrierter Apfelanbau im Vergleich: Ein Zwischenbilanz nach 5 Standjahren [A comparison between organic and integrated apple production: First results after 5 years of observation]. $14^{\text {th }}$ Int. Conf. Organic Fruit Growing. 8. pp. (In German with English summary)

Le Grange, M., Wand, S.J.E. \& Theron, K.I. (2002): Effect of kaolin applications on apple fruit quality and gas exchange of apple leaves. $26^{\text {th }}$ Int. Hort. Congr., Toronto, Canada. Abstracts, 372.

Lurie, S. \& Klein, J.D. (1990): Heat treatment of ripening apples: differential effects on physiology and biochemistry. Physiol. Plant. 78: 181-186.

Lurie, S., Pesis, E. \& Ben-Arie, R. (1991): Darkening of sunscald on apples in storage is a non-enzymatic and non-oxidative process. Postharvest Biol. Technol. 1: 119-125.

Ma, F. \& Cheng, L. (2003): The sun-exposed peel of apple fruit has higher xanthophyll cycle-dependent thermal dissipation and antioxidants of the ascorbate-gluthatione pathway than the shaded peel. Plant Sci. 165: 819-827.

Maxwell, K. \& Johnson, G.N. (2000): Chlorophyll fluorescence a practical guide. J. Exp. Bot. 51: 659-668.

Melgarejo, P., Martínez, J.J., Hernández, F., Martínez-Font, R., Barrows, P. \& Erez, A. (2004): Kaolin treatment to reduce pomegranate sunburn. Scientia Hort. 100: 349-353.

Merzlyak, M.N., Gitelson, A.A., Pogosyan, S.I., Lekhimena, L. \& Chivkunova, O.B. (1998): Light-induced pigment degradation in leaves and ripening fruits studied in situ with reflectance spectroscopy. Physiol. Plant. 104: 661-667.

Merzlyak, M.N., Solovchenko, A.E. \& Chivkunova, O.B. (2002):

Patterns of pigment changes in apple fruits during adaptation to high sunlight and sunscald development. Plant Physiol. Biochem. 40: 679-684.

Meyer, A. (1932): Comparative temperatures of apples. Proc. Amer. Soc. Hort. Sci. 28: 566-567.

Middleton, S., McWaters, A., James, P., Jotic, P., Sutton, J. \& Campbell, J. (2002): The productivity and performance of apple orchard systems in Australia. Compact Fruit Tree 35, (2): 43-47.

Miller, S.S. (1982): Regrowth, flowering, and fruit quality of 'Delicious' apple trees as influenced by summer pruning. J. Amer. Soc. Hort. Sci. 107: 975-978.

O'Connell, M.G. \& Goodwin, I. (2007): Responses of 'Pink Lady' apple to deficit irrigation and partial rootzone drying: Physiology, growth, yield, and fruit quality. Austral. J. Agric. Res. 58, (11): 1068-1076.

Overholser, E.L., Winkler, A.J. \& Jacob, H.E. (1923): Factors influencing the development of internal browning of the Yellow Newton apple. Calif. Agric. Exp. Sta. Bull. 370.

Palmer, J.W., Davies, S.B., Shaw, P.W. \& Wünsche, J.N. (2003): Growth and fruit quality of 'Braeburn' apple (Malus domestica) trees as influenced by fungicide programmes suitable for organic production. New Zealand J. Crop Hort. Sci. 31, (2): 169-177.

Parchomchuk, P. \& Meheriuk, M. (1996): Orchard cooling with pulsed overtree irrigation to prevent solar injury and improve fruit quality of 'Jonagold' apples. Hort. Science 31, (5): 802-804.

Prohens, J., Miró, R., Rodríguez-Burruezo, A., Chiva, S., Verdú, G. \& Nuez, F. (2004): Temperature, electrolyte leakage, ascorbic acid content and sunscald in two cultivars of pepino, Solanum muricatum. J. Hort. Sci. Biotechn. 79, (3): 375-379.

Racskó, J., Wand, S.J.E., Lakatos, L., Miller, D.D., Soltész, M., Szabó, Z., Nyéki, J. \& Costa, C. (2008): A survey of cultivar/ rootstock and orchard management factors influencing the incidence of sunburn damage on apple fruit in Hungary and South Africa. $9^{\text {th }}$ Int. Symp. Integrating Canopy, Rootstock and Environmental Physiology in Orchard Systems. Geneva, NY, USA. Abstracts, 134. (Acta Hort. in press)

Racskó, J., Nagy, J., Szabó, Z., Major, M. \& Nyéki, J. (2005a): The impact of location, row direction, plant density and rootstock on sunburn damage of apple cultivars. Int. J. Hort. Sci. 11, (1): 19-30.

Racskó, J., Szabó, Z., Miller, D.D., Soltész, M. \& Nyéki, J. (2009): Sunburn incidence of apples is affected by rootstocks and fruit position within the canopy but not by fruit position on the cluster. Int. J. Hort. Sci. 15, (4): in press

Racskó, J., Szabó, Z. \& Nyéki, J. (2005b): Importance of supraoptimal radiance supply and sunburn effects on apple fruit quality. Acta Biol. Szegediensis 49, (1-2): 111-114.

Raffo, M.D. \& Iglesias, N. (2004): Efecto de la intercepción y distribución de la radiación fotosintéticamente activa en manzanos cv. Fuji, bajo cuatro sistemas de conducción en alta densidad [Effect of interception and distribution of photosynthetic active radiation in apple cv. Fuji in four high density systems]. RIA 33, (2): 29-42. (In Spanish with English summary)

Reay, P.F. \& Lancaster, J.E. (2001): Accumulation anthocyanins and quercetin-glycosides in 'Gala' and 'Royal Gala' apple fruit skin with UV-B-visible irradiation: modifying effects of fruit maturity, fruit side, and temperature. Scientia Hort. 90: 57-68.

Ritenour, M.A., Kochhar, S., Schrader, L.E., Hsu, T.P. \& Ku, M.S.B. (2001): Characterization of heat shock protein expression in apple peel under field and laboratory conditions. J. Amer. Soc. Hort. Sci. 126: 564-570. 
Ritenour, M.A., Schrader, L.E. \& Ku, M. (1998): The presence of heat-shock proteins in sun-exposed and heat-treated apple fruit. HortScience 33, (3): 452. (Abstract)

Rogoyski, M.K., Gaus, A.G. \& Larsen, H.J. (1993): Reduction of apple sunburn with cellulose fibers. HortScience 28, (5): 224. (Abstract)

Saudreau, M., Sinoquet, H., Santin, O., Marquier, A., Adam, B., Longuenesse, J.J., Guilioni, L. \& Chelle, M. (2007): A 3D model for simulating the spatial and temporal distribution of temperature within ellipsoidal fruit. Agric. Forest Met. 147: 1-15.

Schrader, L.E. (2009): Sunburn of apples: Causes and suppression of sunburn damage. HortScience 44, (4): 991. (Abstract)

Schrader, L.E., Edwards, G.E., Ku, M., Zhang, J-G., Sun, J. \& Duplaga, W.K. (2001): Sunburn in apple. WSU Project, No. 4179, Final Report, 4. p.

Schrader, L.E., Felicetti, D.A., Sun, J., Xu, J-Z., Zhang, J-G. \& Kahn, C.B. (2008): Effects of high temperature and high solar irradiance on sunburn, fruit quality, and skin pigments of apple. $9^{\text {th }}$ Int. Symp. Integrating Canopy, Rootstock and Environmental Physiology in Orchard Systems. Geneva, NY, USA. Abstracts, 58. Acta Hort. (in press)

Schrader, L.E. \& Kahn, C.B. (2009): Internal fruit quality affected by sunburn browning in apples. HortScience 44, (4): 1003. (Abstract)

Schrader, L.E., Zhang, J. \& Sun, J. (2003): Environmental stresses that cause sunburn of apple. Acta Hort. 618: 397-405.

Schrader, L.E., Zhang, J., Sun, J., Xu, J., Elfving, D.J. \& Kahn, C. (2009): Postharvest changes in internal fruit quality in apples with sunburn browning. J. Amer. Soc. Hort. Sci. 134, (1): 148-155.

Schupp, J.R., Fallahi, E. \& Chun, I-J. (2002a): Effect of Surround ${ }^{\circledR}$ particle film on fruit sunburn, maturity and quality of 'Fuji' and 'Honeycrisp' apples. New York Fruit Quart. 10, (1): 9-11.

Schupp, J.R., Fallahi, E. \& Chun, I-J. (2002b): Effect of particle film on fruit sunburn, maturity and quality of 'Fuji' and 'Honeycrisp' apples. HortTechnology 12, (1): 87-90.

Schupp, J.R., Fallahi, E. \& Chun, I-J. (2004): Effect of particle film on fruit sunburn, maturity and quality of 'Fuji' and 'Honeycrisp' apples. Acta Hort. 636: 551-556.

Seo, J.H., Sun, J., Schrader, L.E. \& Tian, J. (2008): Use of chlorophyll fluorescence to assess heat stress in apple fruit. Acta Hort. 772: 279-282.

Smillie, R.M. \& Hetherington, S.E. (1983): Stress tolerance and stress-induced injury in crop plants measured by chlorophyll fluorescence in vivo. Plant Physiol. 72: 1043-1050.

Solovchenko, A.E., Chivkunova, O.B., Merzlyak, M.N. \& Reshetnikova, I.V. (2001): A spectrophotometric analysis of pigments in apples. Russian J. Plant Physiol. 48, (5): 801-808.

Solovchenko, A.E. \& Schmitz-Eiberger, M. (2003): Significance of skin flavonoids for UV-B-protection in apple fruits. J. Exp. Bot. 54: 1977-1984.

Song, J., Fan, L., Forney, C.F. \& Jordan, M.A. (2001): Using volatile emission and chlorophyll fluorescence as indicator of heat injury in apples. J. Amer. Soc. Hort. Sci. 126: 771-777.

Stampar, F., Veberic, R., Zadravec,P., Hudina, M., Usenik, V., Solar, A. \& Osterc, G. (2002): Yield and fruit quality of apples cv. 'Jonagold' under hail protection nets. Gartenbauwiss. 67, (5): 205-210.

Takos, A.M., Jaffé, F.W., Jacob, S.R., Bogs, J., Robinson, S.P. \& Walker, A.R. (2006): Light-induced expression of a $M Y B$ gene regulates anthocyanin biosynthesis in red apples. Plant Physiol. 142: 1216-1232.
Tapia, N.A.F. (2008): Efecto de la altura de planta sobre la calidad y producción de fruta en manzanos cv. Ultra Red Gala sobre portainjerto MM.111 temporada 2007/2008 [Effect of tree height on fruit quality and productivity of Ultra Red Gala apple on MM.111 rootstock in the 2007/2008 season]. MS Thesis, University of Talca, Chile. (In Spanish)

Thorpe, M.R. (1974): Radiant heating of apples. J. Appl. Ecol. 11, (2): 755-760.

Tustin, S.D., Watkins, C.B., Cashmore, W.M. \& Brookfield, P.L. (1993): Sources of variation in fruit quality of 'Braeburn' apple at harvest and after storage. HortScience 28, (5): 86. (Abstract)

Unrath, C.R. (1972): The evaporative cooling effects of overtree sprinkler irrigation on 'Red Delicious' apples. J. Amer. Soc. Hort. Sci. 97, (1): 55-58.

van den Dool, K. (2006): Evaporative cooling of apple and pear orchards. MSc Thesis, Stellenbosch University, South Africa. 95. p.

Wand, S.J.E., Theron, K.I., Ackerman, J. \& Marais, S.J.S. (2006): Harvest and post-harvest apple fruit quality following applications of kaolin particle film in South African orchards. Sci. Hortic. 107: 271-276.

Warrington, I.J., Stanley, C.J., Tustin, D.S., Hirst, P.M. \& Cashmore, W.M. (1996): Light transmission, yield distribution, and fruit quality in six tree canopy forms of 'Granny Smith' apple. J. Tree Fruit Prod. 1, (1): 27-54.

Wellburn, A.R. (1994): The spectral determination of chlorophylls a and $\mathrm{b}$, as well as total carotenoids, using various solvents with spectrophotometers of different resolution. J. Plant Physiol. 144: 307-313. Willits, D.H. \& Peet, M.M. (2001): Measurement of chlorophyll fluorescence as a heat stress indicator in tomato: Laboratory and greenhouse comparisons. J. Amer. Soc. Hort. Sci. 126: 188-194.

Woolf, A.B., Watkins, C.B., Bowen, J.H., Lay-Yee, M., Maindonald, J.H. \& Ferguson, I.B. (1995): Reducing external chilling injury in stored 'Hass' avocados with dry heat treatments. J. Amer. Soc. Hort. Sci. 120: 1050-1056.

Wünsche, J.N., Bowen, J., Ferguson, I., Woolf, A. \& McGhie, T. (2004a): Sunburn on apples - Causes and control mechanisms. Acta Hort. 636: 631-636.

Wünsche, J.N., Greer, D.H., Palmer, J.W., Lang, A. \& McGhie, T. (2001): Sunburn - The cost of a high light environment. Acta Hort. 557: 349-356.

Wünsche, J.N., Lombardini, L. \& Greer, D.H. (2004b): 'Surround' particle film application - Effect on whole canopy physiology of apple. Acta Hort. 636: 565-571.

Yuri, J.A. (2001): El daño por sol en manzanas [Sunburn of apples]. Revista Fruticola 22, (3): 89-96. (In Spanish)

Yuri, J.A., Torres, C. \& Vásquez, Y.J. (2000a): Golpe de sol en manzanas. I. Evaluación del daño y métodos de control [Sunburn on apples. I. Damage evaluation and control methods]. Agro-Ciencia 16, (5): 13-21. (In Spanish with English summary)

Yuri, J.A., Torres, C., Bastías, R. \& Neira, Y.A. (2000b): Golpe de sol en manzanas. II. Factores inductors y respuestas bioquímicas [Sunburn on apples. II. Inducing factors and biochemical responses]. Agro-Ciencia 16, (1): 23-32. (In Spanish with English summary)

Zhang, J-G., Chen, S-C., Li, Y-L., Di, B., Zhang, J-Q. \& Liu, YF. (2008): Effect of high temperature and excessive light stresses on PPO activity in apple peel. Acta Ecol. Sinica 28, (10): 4645-4651.

Zhang, J-G., Di, B., Li, Y-L., Zhang, J-Q., Sun, J. \& Liu, Y. (2007): Effect of microenvironments and exogenous substance application on 5'-nucleotidase activities in apple peel. Front. Agric. China 1, (1): 67-71. 